\title{
Heavy metals removal from synthetic wastewater by a novel nano-size composite adsorbent
}

\author{
Y. B. Onundi; * A. A. Mamun; M. F. Al Khatib; M. A. Al Saadi; A. M. Suleyman \\ Bioenvironmental Engineering Research Unit, Department of Biotechnology Engineering, Faculty of Engineering, \\ International Is lamic University Malaysia, Gombak, 53100 Kuala Lumpur, Malaysia
}

Received 10 November 2010; $\quad$ revised 27 March 2011; accepted 11 August 2011; available online 1 September 2011

\begin{abstract}
The effects of varying operating conditions on metals removal from aqueous solution using a novel nano-size composite adsorbent are reported in this paper. Characterization of the composite adsorbent material showed successful production of carbon nanotubes on granular activated carbon using $1 \%$ nickel as catalyst. In the laboratory adsorption experiment, initial mixed metals concentration of $2.0 \mathrm{mg} / \mathrm{L} \mathrm{Cu}^{2+}, 1.5 \mathrm{mg} / \mathrm{L} \mathrm{Pb}^{2+}$ and $0.8 \mathrm{mg} / \mathrm{L} \mathrm{Ni}{ }^{2+}$ were synthesized based on metals concentration from samples collected from a semiconductor industry effluent. The effects of operation conditions on metals removal using composite adsorbent were investigated. Experimental conditions resulting in optimal metals adsorption were observed at $\mathrm{pH} 5,1 \mathrm{~g} / \mathrm{L}$ dosage and $60 \mathrm{~min}$ contact time. It was noted that the percentage of metals removal at the equilibrium condition varied for each metal, with lead recording $99 \%$, copper $61 \%$ and nickel $20 \%$, giving metal affinity trend of $\mathrm{Pb}^{2+}>\mathrm{Cu}^{2+}>\mathrm{Ni}^{2+}$ on the adsorbent. Langmuir's adsorption isotherm model gave a higher $\mathrm{R}^{2}$ value of $0.93,0.89$ and 0.986 for copper, nickel and lead, respectively, over that of Freundlich model during the adsorption process of the three metals in matrix solution.
\end{abstract}

Keywords: Adsorption; Carbon nanotubes; Granular activated carbon; Isotherm

\section{INTRODUCTION}

Industrialization, uncontrolled use and exploitation of natural resources of the past decades have resulted in increased pollution of the Earth (Bansal and Goyal, 2005). Pollution of the environment by heavy metals is of great concern to governments and environmentalists due to their detrimental effect on a variety of living species (Issabayeva et al., 2007). Pollution of the environment in Malaysia by heavy metals is mainly by electroplating and metal treatment / fabrication industries located in the west coast of the peninsular Malaysia (DOE, 1979; Issabayeva et al., 2007). Research on finding more efficient technology for wastewater treatment to meet prevalent safe standards is constantly receiving the attention of environmental scientists around the world. Previous wastewater treatment efforts had led to the development of various treatment technological options which involved the application of unit operations or unit processes such as chemical precipitation, coagulation, adsorption, ion exchange

* *Corresponding Author Email: mamun@iium.edu.my _Tel: +6036196 4440, Fax: +603 61964442 and membrane filtration (Georg and Max, 2008). Furthermore, among aforementioned treatment technologies, adsorption had been reported as the most technically and economically viable option (Onundi et al., 2010). Furthermore, research in wastewater treatment by adsorption has resulted in development of different materials for removal of metals from solutions, these materials include: natural product (Nouri et al., 2009; 2011), activated carbon (Issabayeva et al., 2006; Onundi et al., 2010), zeolites, aluminosilicate (Samuel and Osman, 1987), peat kaolin and clay (Chantawong et al., 2003) and polysaccharides (Bong et al., 2004). Recently, Carbon nanomaterials (CNMs) mainly in the form of Carbon nanotubes (CNTs) and Carbon nanofibers (CNFs) are being used as new adsorbents with superior performance due to their high specific surface area and high aspect ratio. Work on the effect of morphology, surface functional groups on adsorption capacity of heavy metals by CNMs had been carried out (Nora and Mamadou, 2005; Kabbashi et al., 2009; Atafar et al., 2010). Work of Li et al. (2003) reported Multiwall carbon nanotubes (MWCNTs) as having metal-ion 
sorption capacity of 3-4 times larger than the widely used powder and Granular activated carbon (GAC). Furthermore, CNTs with rougher surfaces were observed as having improved metal ions adsorption capacity compared to smooth surface ones (Li et al., 2007). However, handling and separation of these CNMs materials from the filtrate were noted as posing a challenge in the application of nanomaterials in water treatment (Nora and Mamadou, 2005). Success had been made in the synthesis of composite nanoscale carbon materials on a macroscale substrate (Vieira et al., 2004; Pingle and Lefferts, 2006; Zhang et al., 2008; Zhou et al., 2009) which could reduce the challenge with the handling of these nano-size materials, however application of these composite materials in metal removal from solution is yet to be extensively investigated. This work explores the possibilities of synthesizing CNT on GAC to form a composite material CNT-GAC and studying the adsorption mechanism of the nano-size composite adsorbent in the removal of copper, nickel and lead ions from aqueous solution. Langmuir and Freundlich isotherm models were employed to describe the adsorption process and the effects of adsorbate $\mathrm{pH}$ variation, contact time and adsorbent dosage on metal removal were investigated. The production of CNT-GAC composite adsorbent and effect of $\mathrm{pH}$, contact time and adsorbent dosage on metals adsorption from aqueous solution are reported in this paper. This work was done in 2010, at Bioenvironmental Engineering Research Unit (BERU) of the International Islamic University Malaysia (IIUM).

\section{MATERIALS AND METHODS}

Industrial wastewater samples from a semiconductor company (located at Kuala Langat, Malaysia) were collected, preserved and tested for metals content following standard methods (APHA et al., 2005) procedures. The concentration of heavy metals, namely lead, nickel and copper in the industrial wastewater served as the bases for the adsorption study in the laboratory.

\section{Adsorbate}

Metals solutions of copper, lead and nickel ions of $1000 \mathrm{mg} / \mathrm{L}$ in nitric acid were purchased from Fisher Scientific UK. These were used to produce aqueous solutions of the three metals in a mixed solution, based on the 5-day average metal concentration from samples of actual industrial effluent mentioned above.
Adsorbent

Palm kernel shell based GAC used as substrate material for the CNT production was bought from KDTechnology Malaysia. The synthesis of CNT on the GAC was carried out in stages. The first stage involved impregnation of nickel onto GAC using $1 \%$ $(\mathrm{w} / \mathrm{w})$ nickel catalyst $\left[\mathrm{Ni}\left(\mathrm{NO}_{3}\right)_{2}\right]$. The nickel catalyst served as seed to nucleate the growth of CNT. The impregnated GAC was then dried overnight in a sonicator water bath at $56{ }^{\circ} \mathrm{C}$. The dry mixture was placed in a thermal Chemical vapour deposition (CVD) reactor for calcination of the mixture by passing $\mathrm{N}_{2}$ gas at a flow rate of $300 \mathrm{~mL} / \mathrm{min}$ under $300{ }^{\circ} \mathrm{C}$ for one hour to convert the nickel salt into corresponding nickel oxide. The nickel catalyst attached to the surface of the GAC was then reduced to nickel at $300{ }^{\circ} \mathrm{C}$ for another hour in presence of $\mathrm{H}_{2}$ gas at a flow rate of $300 \mathrm{~mL} / \mathrm{min}$. The final stage of synthesis was carried out in the same tubular CVD reactor at atmospheric pressure by passing carbon source $\mathrm{C}_{2} \mathrm{H}_{2}$ (acetylene gas) at a flow rate of $50 \mathrm{~mL} / \mathrm{min}$ in conjunction with the hydrogen gas for one hour at $750{ }^{\circ} \mathrm{C}$. The novel CNT-GAC adsorbent was cooled to room temperature in the presence of $\mathrm{N}_{2}$ gas in the reactor, before washing it with distilled water to remove fines. The wet CNTGAC was then dried at $110{ }^{\circ} \mathrm{C}$ for two hours and subsequently used for absorption studies at ambient room temperature of $27^{\circ} \mathrm{C}( \pm 2)$.

\section{Adsorbent characterization}

Field emission scanning electron microscope (FESEM, brand Jeoul Jsm-6700F) was employed to study the morphology of the CNT-GAC material, while transmission electron microscope (TEM, brand Jeoul Jem-2010) was used to check the inner structure of the CNT-GAC. Samples of CNT-GAC for Fourier transform infrared (FTIR) analysis were prepared by diluting the adsorbent to $5 \%$ in $\mathrm{KBr}$ and cast in disks for analysis to obtain the spectrum from a PerkinElmer precisely of model 100, same procedure was followed by Zvinowanda et al. (2009). Specific surface area of the CNT-GAC was measured by Coulter sorptometer machine of model SA-3100, using $\mathrm{N}_{2}$ as adsorbent at the liquid nitrogen temperature of $-196^{\circ} \mathrm{C}$.

\section{Adsorption study}

For each experiment, $50 \mathrm{~mL}$ of synthetic water sample containing mixed metals of $2.0 \mathrm{mg} / \mathrm{L} \mathrm{Cu}, 1.5$ $\mathrm{mg} / \mathrm{L} \mathrm{Pb}$ and $0.8 \mathrm{mg} / \mathrm{L} \mathrm{Ni}$, was prepared based on 
industrial wastewater metal concentration and added to a calculated amount of adsorbent in $100 \mathrm{~mL}$ shake flask. The $\mathrm{pH}$ adjustment of solution was done using $1.0 \mathrm{M}$ $\mathrm{HCL}$ and $1.0 \mathrm{M} \mathrm{NaOH}$. The adsorbent in solution was agitated in a mechanical shaker at a speed of $100 \mathrm{rpm}$ at $27^{\circ} \mathrm{C}( \pm 2)$. Blank solutions were treated similarly without the adsorbent and under control condition as suggested by Goel et al. (2005). The solution was filtered using a Whatman ${ }^{\circledR} 0.45 \mu \mathrm{m}$ filter paper. The results were analyzed for the residual concentration of metals in the filtrate by Atomic adsorption spectrophotometer (ASS) model HGA900.

Equilibrium concentration of metals at different adsorbent dosage $(1,2,3$ and $4 \mathrm{~g} / \mathrm{L})$ at ambient temperature was used for the isotherm study. Isotherm studies at equilibrium constant concentration of metals was investigated using the two most widely used model equations of Freundlich (Freundlich and Hatfield, 1926) and Langmuir (Langmuir, 1918).

\section{RESULTS AND DISCUSSION}

The macro size composite CNT-GAC was easier to handle in the laboratory than the pure CNT. It was observed that the filtrate after adsorption experiment was clear, having no visible CNT-GAC remaining in solution. This indicates that the macro size composite CNT-GAC retained the CNT on the GAC surface after adsorption, reducing membrane fouling, solving the separation problems earlier recorded in literature and also eliminating the need to centrifuge the filtrate before using the AAS machine.

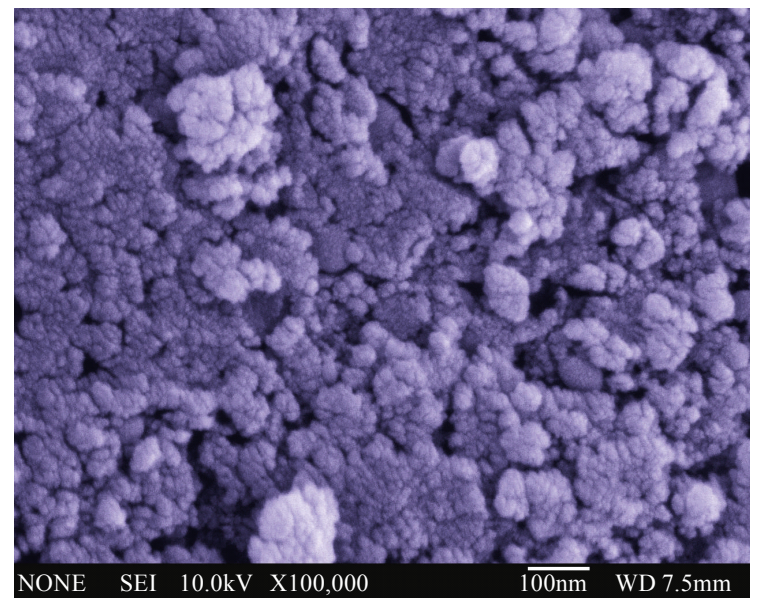

Fig. 1: FESEM Image of GAC surface
Physical and chemical characterization of the adsorbent

The surface of the substrate GAC before the growth of CNT was largely porous as shown in Fig.1. The morphology of the CNT-GAC as observed by FESEM machine in Fig. 2 shows that the structures were twisted with a rough surface, having average outer diameter of $50 \mathrm{~nm}$.

The TEM images as shown in Fig. 3 and 4 revealed the morphology of the CNT-GAC as MWCNT with average internal hollow diameter of $30 \mathrm{~nm}$, with a caped end. This observed structure of CNT on the GAC is inline with the observation reported by Shoushan et al. (1999), Chai-chih et al. (2008) and Zhang et al. (2008) when CNT was produced at same temperature range. Other properties of the substrate GAC and the produced CNT-GAC are shown in Table 1.

The FTIR analysis of CNT-GAC is shown in Fig. 5 and a summary of the peaks and their assignments are given in Table 2. As can be inferred from the FTIR analysis, the acidic functional groups were: carboxyl, carbonyl, lactones and sulphur groups. Generally, these acidic groups on carbon surface produce cation exchange properties (Goel et al., 2005; Edwin, 2008) and these had been reported to be responsible for higher adsorption of metal ions on carbon surface. Specifically sulphur groups were reported by Goel et $a l$. (2005) as aiding lead ions adsorption. In solution, the dissociation of carboxylic surface groups facilitates the dispersion of the carbon in water by

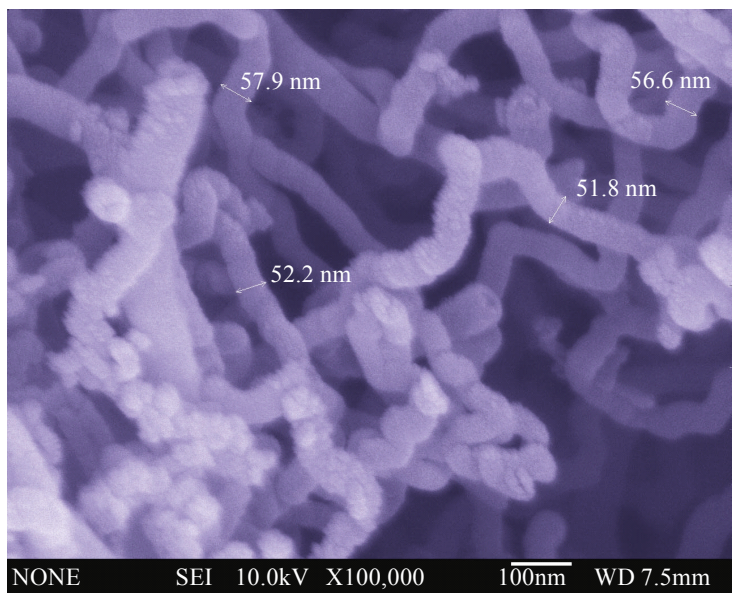

Fig. 2: FESEM Image of CNT grown on GAC surface 


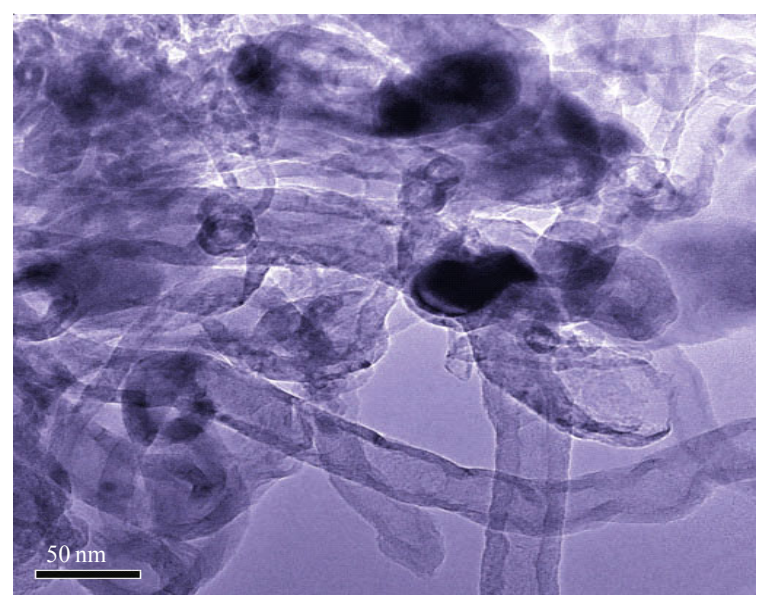

Fig. 3: TEM image of the CNT grown on GAC

creating a negative surface charge (Chen et al., 1996). Chen and Wang (2002) emphasized that higher content of carboxylic functional groups could significantly improve adsorption of metal due to the high affinity between them.

\section{Effect of pH on adsorption}

The $\mathrm{pH}$ of the solution had been reported to be important factor in adsorption processes (Corapcioglu and Huang, 1987). The variations in adsorption capacity of CNT-GAC with increasing $\mathrm{pH}$ is shown in Fig. 6, it could be inferred that the adsorption capacity of CNTGAC increased as solution $\mathrm{pH}$ increased from $\mathrm{pH} 3$ to 5 and capacity decreases above $\mathrm{pH} 5$.

The mechanism of metals adsorption by the adsorbent CNT-GAC could be explained as follows: the metals (copper, lead and nickel) ions exist predominately as $\mathrm{M}(\mathrm{II})$ ions in highly acidic $\mathrm{pH}$ range of 2 to 3 . The minimum adsorption observed at low $\mathrm{pH}$ could be related to the higher concentration and mobility of $\mathrm{H}^{+}$ions, which is favored by high solubility and ionization of metallic salts in acid medium. Thus suggesting that at lower $\mathrm{pH}$ value, the surface of the adsorbent is surrounded by hydronium ions, thereby preventing metals ions from approaching the binding sites of the adsorbents. Thus, at higher $\mathrm{H}^{+}$ concentration, the adsorbents' surface becomes more positively charged such that the attraction between adsorbents and metal cations is reduced. In contrast, as the $\mathrm{pH}$ increases, more negatively charged surface becomes available thus facilitating greater metals removal. Thus, the sorption of metal cations increased with increasing $\mathrm{pH}$ as the metal ionic species become

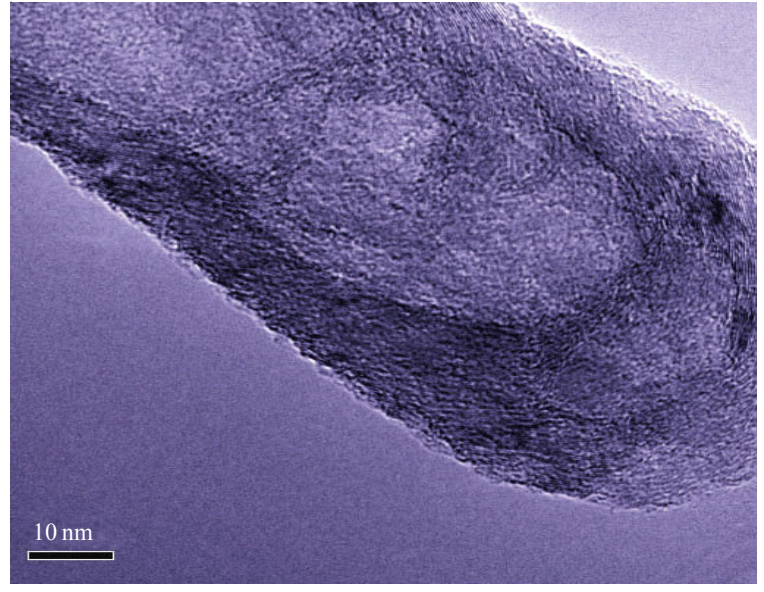

Fig. 4: End cap of the multi-walled CNT on GAC

less stable in the solution. The maximum adsorption observed in the $\mathrm{pH} 5$ and the subsequent reduction in adsorption capacity was probably due the partial hydrolysis of metal ions, resulting in the formation of $\mathrm{M}(\mathrm{OH})^{+}$ions and $\mathrm{M}(\mathrm{OH})_{2}$, which would be adsorbed to a greater extent on a less-polar carbon surface of the adsorbents compared to $\mathrm{M}^{2+}$ ions (Onundi et al., 2010). Furthermore, the low solubility of hydrolyzed metals species would have resulted into precipitation of metals at $\mathrm{pH}$ above 5 , thereby reducing adsorption capacity of CNT-GAC.

\section{Effect of contact time}

The result of the effect of contact time on percentage metal removal at $\mathrm{pH} 5$ is represented in Fig.7. The adsorption rate was observed as rapid in the first $5 \mathrm{~min}$, followed by a gradual decrease with time until equilibrium adsorption was noticed at $60 \mathrm{~min}$. The fast adsorption at the initial stage was probably due to the initial concentration gradient between the adsorbate in solution and the number of vacant sites available on the CNT-GAC surface. The progressive decrease in adsorption rate and consequently the attainment of equilibrium adsorption might have been due to reduction in the available active adsorption sites on the adsorbent with time resulting to limited mass transfer of the adsorbate molecules from the bulk liquid to the external surface of CNT-GAC. It was noted that the sorption capacities corresponding to equilibrium varied for each metal, with lead ions recording $99 \%$, copper $61 \%$ and nickel $20 \%$, giving metal affinity trend of $\mathrm{Pb}^{2+}>\mathrm{Cu}^{2+}>\mathrm{Ni}^{2+}$ on the CNT-GAC. The observed trend was in agreement to the findings of Goel et al. 
Table 1: Properties of substrate GAC and novel CNT-GAC

\begin{tabular}{lcc}
\hline Parameters & GAC & CNM \\
\hline Raw material & Palm kernel shell & Palm kernel shell and CNT \\
Particle size $(\mathrm{mm})$ & $1.68-2.38$ & $1.68-2.38$ \\
Ash content & $4 \% \max$ & $5 \% \max$ \\
Density $\left(\mathrm{g} / \mathrm{cm}^{3}\right)$ & 0.864 & 0.784 \\
Surface area $\left(\mathrm{m}^{2} / \mathrm{g}\right)(\mathrm{BET})$ & 513.3 & 300.1 \\
Average pore size $(\mathrm{A})$ & 48.5 & 52.34 \\
Total pore volume $(\mathrm{cc} / \mathrm{g})$ & 0.622 & 0.393 \\
& & \\
Elemental analysis $(\%)$ & & \\
$\mathrm{C}$ & 64.45 & 57.60 \\
$\mathrm{~N}$ & 23.09 & 26.22 \\
O & 00.00 & 0.44 \\
Others & 32.09 & 68.18 \\
\hline
\end{tabular}

Table 2: Peaks from CNT spectrum by FTIR

\begin{tabular}{ll}
\hline $\begin{array}{l}\text { CNT-GAC } \\
\text { band position }(1 / \mathrm{cm})\end{array}$ & \multicolumn{1}{c}{ Possible assignments } \\
\hline 3448 & $\begin{array}{l}\text { O-H stretching (intermolecular } \\
\text { diametric) }\end{array}$ \\
3200 & C-H stretching (alkenes) carboxyl \\
2045 & C $=\mathrm{N}$ stretching (alkynes) \\
1697 & C=O Stretching (aldehydic) carbonyl \\
647 & S-O Bends (sulfates) \\
\hline
\end{tabular}

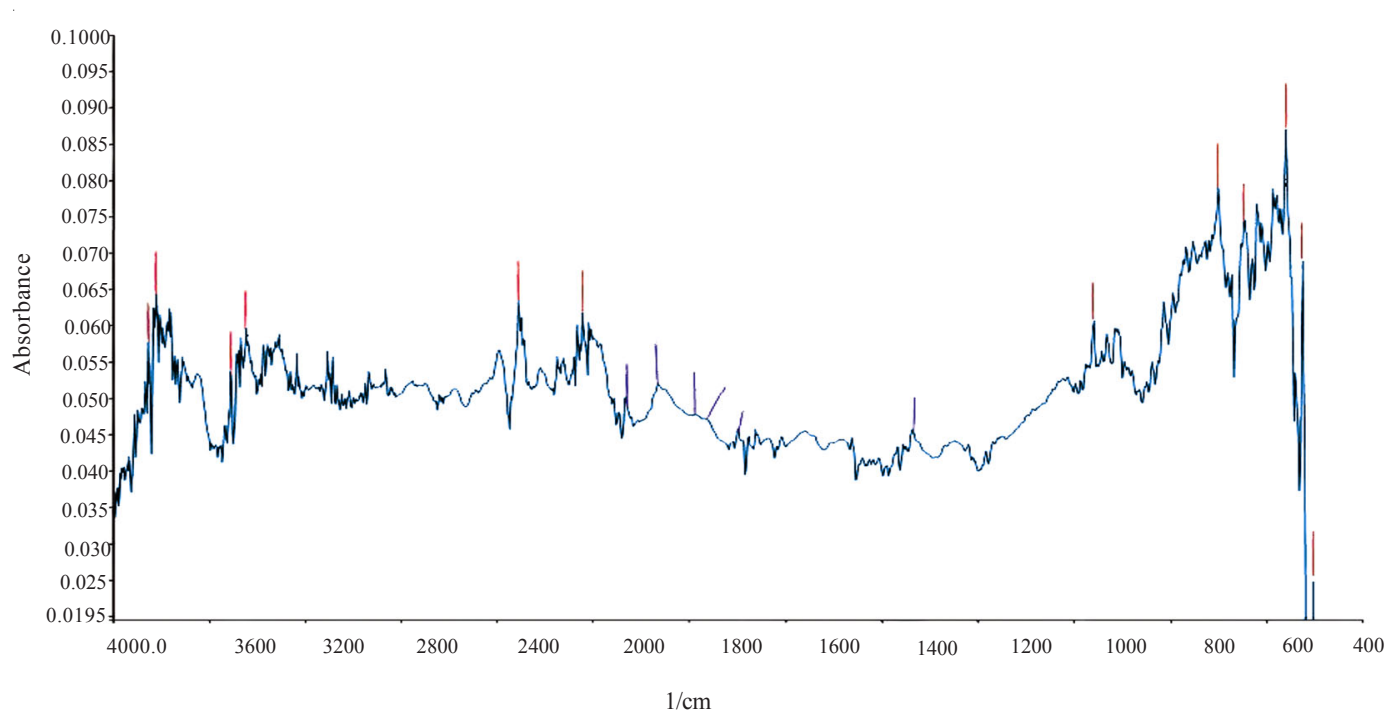

Fig. 5: FTIR Spectrum of CNT-GAC

(2005), who suggested that the presence of sulphur functional group on adsorbent favours lead ionsselective sorption.

\section{Effect of adsorbent dosage}

The result of variation of adsorbent capacity with increment in dosage using a contact time of $60 \mathrm{~min}$. at pH 5 is shown in Fig.8. It was observed that as the dosage increased from 0.5 to $1 \mathrm{~g} / \mathrm{L}$ the metals adsorption capacity increased from $0.119 \mathrm{mg} / \mathrm{g}$ to $0.853 \mathrm{mg} / \mathrm{g}$ for lead ions, while capacity for copper ions increased from $0.109 \mathrm{mg} / \mathrm{g}$ to $1.013 \mathrm{mg} / \mathrm{g}$. A decline in capacity was noticed beyond $1 \mathrm{~g} / \mathrm{L}$ dosage for copper and lead ions; however the capacity for nickel ions increased from 0.01 $\mathrm{mg} / \mathrm{g}$ at $1 \mathrm{~g} / \mathrm{L}$ dosage to a maximum of $0.07 \mathrm{mg} / \mathrm{g}$ at 2 $\mathrm{g} / \mathrm{L}$. This implies that optimum dosage lies around $1 \mathrm{~g} / \mathrm{L}$ to $2 \mathrm{~g} / \mathrm{L}$, therefore further increment in dosage does not result to a significant increment in adsorption capacity.

The initial increment in adsorption capacity with increase in adsorbent dosage was expected because as the adsorbent dose increases the number of adsorbent particles increases, thus more surface areas were available for metals attachment, similar trend was reported by Acharya (2009). It is plausible to suggest that with higher dosage of adsorbent there would be greater availability of exchangeable sites for metal ions (Acharya, 2009). As noticed in Fig. 8, further increment in adsorbent dosage beyond maximum adsorption capacity (at $1 \mathrm{~g} / \mathrm{L}$ for $\mathrm{Cu}^{2+}$ 


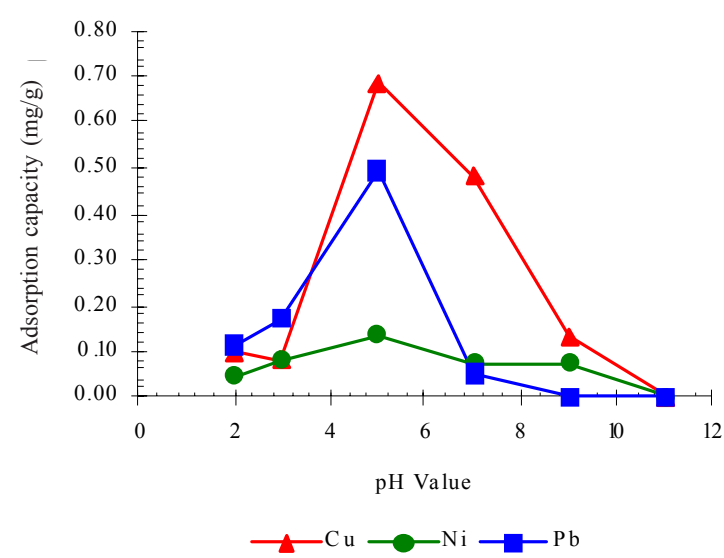

Fig. 6: Effect of $\mathrm{pH}$ on adsorption of metals onto CNT-GAC from a mixed solution (adsorbent dosage $=0.5 \mathrm{~g} / \mathrm{L}$, agitation $=100 \mathrm{rpm}$ and time $=60 \mathrm{~min}$ )

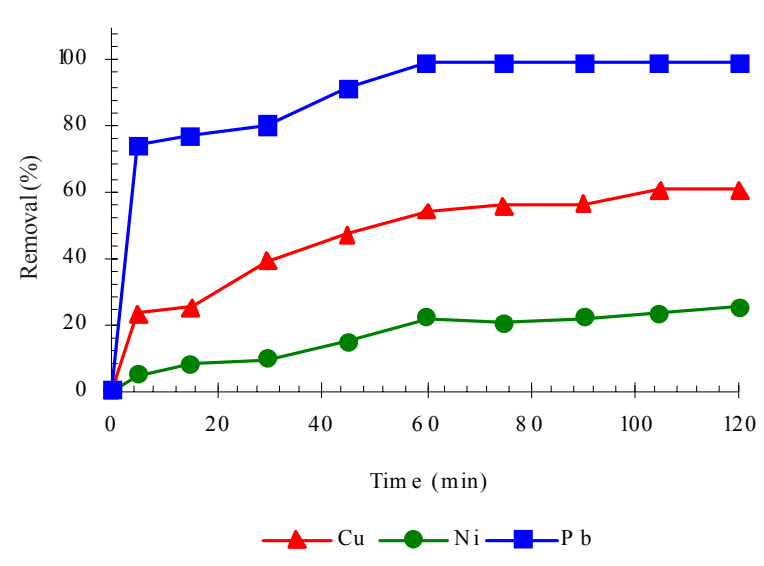

Fig. 7: Effect of contact time on adsorption of $\mathrm{Cu}(\mathrm{II}), \mathrm{Ni}(\mathrm{II})$ and $\mathrm{Pb}$ (II) (constant temperature $=27( \pm 2)^{\circ} \mathrm{C}, \mathrm{pH}=4$ and adsorbent dose $=4 \mathrm{~g} / \mathrm{L}$ )

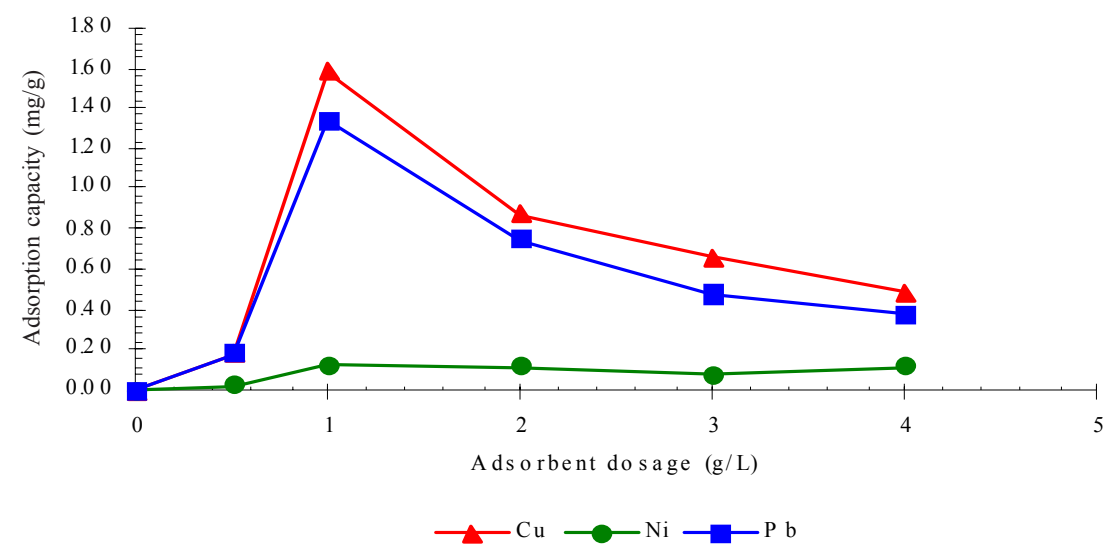

Fig. 8: Effect of adsorbent dosage $(\mathrm{g} / \mathrm{L})$ on metals adsorption capacity (in $50 \mathrm{~mL}$ solution at $\mathrm{pH} 5$, agitation period $=60 \mathrm{~min}$, agitation speed at $=100 \mathrm{rpm}$, metals having different initial concentration)

Table 3: Isotherm parameters for metals adsorption at $27( \pm 2){ }^{\circ} \mathrm{C}$ and $\mathrm{pH} 5$

\begin{tabular}{|c|c|c|c|c|c|}
\hline Metals & Equation & & & $\mathrm{C}_{\mathrm{s}}$ (equation) & $\mathrm{R}^{2}$ \\
\hline \multirow{2}{*}{ Copper } & Langmuir & $\mathrm{a}=0.889$ & $\mathrm{~b}=3.5961$ & $C_{S}=\frac{x}{m}=\frac{(0.8892)(3.5961)}{1+3.5961 C_{e}}$ & 0.928 \\
\hline & Freundlich & $\mathrm{K}_{\mathrm{f}}=-0.098$ & $\mathrm{n}=1.9305$ & $C_{s}=\frac{x}{m}=0.09785 \cdot c_{e}^{1 / 1.9305}$ & 0.850 \\
\hline \multirow{2}{*}{ Nickel } & Langmuir & $\mathrm{a}=-0.069$ & $\mathrm{~b}=-0.8656$ & $C_{S}=\frac{x}{m}=\frac{(-0.06927)(-0.86564)}{1-0.86564 C_{e}}$ & 0.889 \\
\hline & Freundlich & $\mathrm{K}_{\mathrm{f}}=-0.536$ & $\mathrm{n}=0.3825$ & $C_{S}=\frac{x}{m}=0.5365 . c_{e}^{1 / 0.3825}$ & 0.726 \\
\hline \multirow{2}{*}{ Lead } & Langmuir & $a=0.682$ & $b=86.2609$ & $C_{S}=\frac{x}{m}=\frac{(0.6824)(83.2609)}{1+83.2609 C_{e}}$ & 0.986 \\
\hline & Freundlich & $\mathrm{K}_{\mathrm{f}}=-0.052$ & $\mathrm{n}=14.1581$ & $C_{S}=\frac{x}{m}=-0.05166 \cdot c_{e} e^{1 / 4.1581}$ & 0.905 \\
\hline
\end{tabular}


and $\mathrm{Pb}^{2+}, 2 \mathrm{~g} / \mathrm{L}$ for $\mathrm{Ni}^{2+}$ ) caused a decline. This reduction in capacity could be due to the overlapping of the adsorption sites as a result of overcrowding of adsorbent particles when the adsorbent dosage is increased above $2 \mathrm{~g} / \mathrm{L}$. This imposed a screening effect on the dense outer layer of the adsorbent, thereby shielding the binding sites from metals as explained by Garg et al. (2003) and Babel and Kurniawan (2004).

\section{Equilibrium adsorption isotherms}

The equilibrium adsorption data was fitted into the Langmuir and Freundlich equations to yield the model parameters with correlation coefficients $\left(\mathrm{R}^{2}\right)$ shown in Table 3. It was observed that results fitted better in the Langmuir model in terms of $\mathrm{R}^{2}$ value, recording 0.99 for lead, 0.93 for copper and 0.89 for nickel. The trend of affinity for metals by the CNT-GAC surface observed in terms of constant "a" was $\mathrm{Cu}^{2+}>\mathrm{Pb}^{2+}>\mathrm{Ni}^{2+}$. This could have been due to the initial concentration of metals following same trend. While the affinity of the metals for the adsorbent surface in terms of value " $b$ " in the Table 3 varied in the trend $\mathrm{Pb}^{2+}>\mathrm{Cu}^{2+}>\mathrm{Ni}^{2+}$, this was probably due to the acidic functional groups present on the CNTGAC surface. Particularly the sulphate group is assumed to favour lead ions adsorption over other metals, while the other acidic group generally favours metals adsorption.

\section{CONCLUSION}

A novel CNT-GAC composite was successfully produced which was easier to handle compared to pure nanomaterial alone. The thermal CVD process reported here was a cleaner method compared to floating catalyst CVD process for CNT production, as the CNT were synthesized on relatively large substrate GAC. Experimental results on adsorption conditions indicated that copper, nickel and lead ions have highest adsorption capacity at $\mathrm{pH} 5$, while the maximum adsorbent dosage was $1 \mathrm{~g} / \mathrm{L}$ for copper and lead ions recording a sorption capacity of 1.013 and $0.853 \mathrm{mg} / \mathrm{g}$ respectively, and $2 \mathrm{~g} / \mathrm{L}$ for nickel recording $0.07 \mathrm{mg} / \mathrm{g}$. Langmuir isotherm adsorption model having higher $\mathrm{R}^{2}$ value of $0.93,0.89$ and 0.99 for copper, nickel and lead ions, respectively, described the adsorption process better than Freundlich model for the three metals. This novel material opens new door for various usage of the nanomaterials in different fields of application in the chemical, petrochemical industries and wastewater treatment plants, though more work is needed for the mass production of the material at reduced cost.

\section{ACKNOWLEDGEMENTS}

The authors wish to acknowledge the Endowment Fund Type A (EDW A 09-449) of International Islamic University Malaysia (IIUM) for funding the research. Assistance from all members of Nanoscience and Nanotechnology Research Group (NANORG) and Bioenvironmental Research Unit (BERU) of the Faculty of Engineering IIUM is very much appreciated.

\section{REFERENCES}

Acharya, J.; Sahu, J. N.; Mohanty, C. R.; Meikap, B. C., (2009). Removal of lead (II) from wastewater by activated carbon developed from Tamarind wood by zinc chloride activation. J. Chem. Eng., 149, 249-262 (14 pages).

APHA; AWWA; WEF, (2005). Standard methods for the examination of water and wastewater. $21^{\text {st }}$ edition. American Public Health Association, American Water Works Association and the Water Environment Federation. Washington DC., USA.

Atafar, Z.; Mesdaghinia, A.; Nouri, J.; Homaee, M.; Yunesian, M., (2010). Effect of fertilizer application on soil heavy metal concentration. Environ. Monitor. Assess., 160 (1-4), 83-89 (7 pages).

Babel, S.; Kurniawan, T. A., (2004). Cr (VI) removal from synthetic wastewater using coconut shell charcoal and commercial activated carbon modified with oxidizing agents and/or chitosan.Chemosphere, 54 (7), 951-967 (17 pages).

Bansal, R. C.; Goyal, M., (2005). Activated Carbon Adsorption. London, Taylor and Francis Group, 351-353 (3 pages).

Bong, K. P.; Seung, H. S.; Young, J. Y., (2004). Selective Biosorption of Mixed Heavy Metal Ions using Polysaccharides. Korean J. Chem. Eng., 21 (6), 1168-1172 (5 pages).

Chai-Chih, C.; Wei-Long, L.; Wen-Jauh, C.; Jin-Hua, H., (2008). Temperature and substrate dependence of structure and growth mechanism of carbon nanofiber. Appl. Surf. Sci., 254, 4681-4687 (7 pages).

Chantawong, V.; Harvey, N. W.; Bashkin, V. N., (2003). Comparison of Heavy Metals Adsorption by Thai Kaolin and Ballclay. Water Air Soil Poll., 148, 111-125 (15 pages).

Chen, J.; Yiacoumi, S.; Blaydes, T. G., (1996). Equilibrium and kinetic studies of copper adsorption by activated carbon. Sep. Tech., 6, 33-146 (114 pages).

Chen, J. P.; Wang, X., (2002). Removing copper, zinc, and lead ion by granular activated carbon in pretreated fixedbed columns. Sep. Purif. Tech., 19, 157-167 (10 pages).

Corapcioglu, M. O.; Huang, C. P., (1987). The adsorption of heavy metals onto hydrous activated carbon.Water Res., 21 (9), 1031-1044 (14 pages).

Department of Environment-DOE., (1979). Environmental Quality (Sewage and industrial effluents) Regulations 1978, In: Environmental Quality Act 1974. E-publishing Lawnet, Malaysia (34 pages).

Edwin, V. A., (2008). Surface Modification of Activated Carbon for enhancement of Nickel (II) adsorption. E-J. Chem., 5 (4), 814-819 (5 pages).

Freundlich, H.; Hatfield, H., (1926). Colloid and Capillary Chemistry. Methuen and Co. Ltd., London. 
Garg, V. K.; Gupta, R.; Yadav, A. B.; Kumar, R. D., (2003). Dye removal from aqueous solution by adsorption on treated sawdust. Bioresour. Tech., 89 (2), 121-124 (5 pages).

Georg, S.; Max, B., (2008). Adsorption of ions onto high silica volcanic glass. Appl. Rad. Iso., 66 (1), 1-8 (8 pages).

Goel, J.; Krishna, K.; Chira, R.; Vinod, K., (2005). Removal of lead (II) by adsorption using treated granular activated carbon and column studies. J. Hazard. Mater., 125 (1-3), 211-220 (9 pages).

Issabayeva, G.; Aroua, M. K.; Sulaiman, N. M., (2007). Continuous adsorption of lead ions in a column packed with palm shell activated carbon. J. Hazard. Mater., 155 (1-2),109113 (4 pages).

Issabayeva, G.; Aroua M. K.; Sulaiman, N. M., (2006). Electrodeposition of copper and lead on palm shell activated carbon in a flow-through electrolytic cell. Desalination, 194 ( $1-3), 192-201$ (9 pages).

Kabbashi, N. A.; Atieh, A. M.; Mamun, A. A.; Mirghani, M. E. S.; Alam M. Z.; Yahya N., (2009). Kinetic Adsorption of Application of Carbon Nanotubes for $\mathrm{Pb}(\mathrm{II})$ Removal from Aqueous Solution. J. Environ. Sci., 21, 539-544 (5 pages).

Langmuir, I., (1918). The adsorption of gases on plane surfaces of glass, mica and platinum. J. Am. Chem. Soc., 40 (8), 1361-1403 (43 pages).

Li, Y. H.; Ding, J.; Luan, Z. K.; Di, Z. C.; Zhu, Y. F.; Xu, C. L; Wu, D. H.; Wei, B. Q., (2003). Competitive adsorption of $\mathrm{Pb}^{2+}, \mathrm{Cu}^{2+}$ and $\mathrm{Cd}^{2+}$ ions from aqueous solutions by multiwalled carbon nanotubes. Carbon, 41, 2787-2792 (6 pages).

Li, Y. H.; Zhao, Y. M.; Hu, W. B.; Ahmad, I.; Zhu, Y. Q.; Peng, X. J.; Luan Z. K., (2007). Carbon nanotubes-the promising adsorbent in wastewater treatment. J. Phys., 61, 698-702 (5 pages).

Nora, S.; Mamadou, S. D., (2005). Nanomaterials and Water Purification: Opportunities and Challenges. J. Nanoparticle Res., 7 (4-5), 331-342 (12 pages).

Nouri, J.; Khorasani, N.; Lorestani, B.; Karami ; M. ; Hassani, A. H.; Yousefi, N., (2009). Accumulation of heavy metals in soil and uptake by plant species with phytoremediation potential. Environ. Earth Sci., 59 (2), 315-323 (9 pages).

Nouri, J.; Lorestani, B.; Yousefi, N.; Khorasani, N.; Hasani, A. H.; Seif, S.; Cheraghi, M., (2011). Phytoremediation potential of native plants grown in the vicinity of Ahangaran lead-zinc mine (Hamedan, Iran). Environ. Earth Sci., 62 (3), 639-644 (6 pages).

Onundi, Y. B.; Mamun, A. A.; Al Khatib, M. F.; Ahmed, Y. M., (2010). Adsorption of copper, nickel and lead ions from synthetic semiconductor industrial wastewater by palm shell activated carbon. Int. J. Environ. Sci. Tech., 7

(4), 751-758 (8 pages).

Pingle, L.; Lefferts, L., (2006). Preparation of Carbon Nanofiber Washcoat on Porous Silica Foam as Structured Catalyst Support. Chin. J. Chem. Eng., 14, 294-300 (7 pages).

Samuel, D. F.; Osman, M. A., (1987). Adsorption Processes for Water Treatment, Butterworths, U.S.A.

Shoushan, F.; Michael, G. C.; Nathan, R. F.; Thomas, W. T.; Alan, M. C.; Hongjie, D., (1999). Self-oriented regular arrays of carbon nanotubes and their field emission properties. Science, 283, 512-514 (3 pages).

Vieira, R.; Ledoux, M. J.; Huu, C. P., (2004). Synthesis and characterization of carbon nanofibres with macroscopic shaping formed by catalytic decomposition of $\mathrm{C}_{2} \mathrm{H}_{6} / \mathrm{H}_{2}$ over nickel catalyst. J. Appl. Catal. A., 274, 1-8 (8 pages).

Zhang, Y.; Qina, Y.; Suna, X; Zhanga, J.; Jinga, C., (2008). Synthesis of carbon nanotube using cesium carbonates catalyst by chemical vapor deposition. Mater Lett., 62 (2122), 3776-3778 (3 pages).

Zhou, J. H.; Zhang, M. G.; Zhao, L.; Lia, P.; Zhou, X. G.; Yuana, W. K., (2009). Carbon nanofiber/graphite-felt composite supported Ru catalysts for hydrogenolysis of sorbitol. Catal. Today, 147, 225-229 (5 pages).

Zvinowanda, C. M.; Okonkwo, J. O.; Shabalala, P. N.; Agyei, N. M., (2009). A novel adsorbent for heavy metal remediation in aqueous environments. Int. J. Environ. Sci. Tech., 6 (3), 425-434 (10 pages).

\begin{abstract}
AUTHOR (S) BIOSKETCHES
Onundi, Y. B., M.Sc., Department of Biotechnology Engineering, Faculty of Engineering, International Islamic University Malaysia (IIUM), Jalan Gombak, 53100 Kuala Lumpur, Malaysia, Kuala Lumpur, Malaysia. Email: onudy1759@gmail.com
\end{abstract}

Mamun, A. A., Ph.D., Department of Biotechnology Engineering, Faculty of Engineering, International Islamic University Malaysia (IIUM), Jalan Gombak, 53100 Kuala Lumpur, Malaysia, Kuala Lumpur, Malaysia. Email: mamun@iium.edu.my

Al Khatib, M. F., Ph.D., Department of Biotechnology Engineering, Faculty of Engineering, International Islamic University Malaysia (IIUM), Jalan Gombak, 53100 Kuala Lumpur, Malaysia, Kuala Lumpur, Malaysia. Email: maan@iium.edu.my

AlSaadi, M. A., M.Sc., Department of Biotechnology Engineering, Faculty of Engineering, International Islamic University Malaysia (IIUM), Jalan Gombak, 53100 Kuala Lumpur, Malaysia, Kuala Lumpur, Malaysia. Email: mdsd68@yahoo.com

Suleyman, A. M., Ph.D., Department of Biotechnology Engineering, Faculty of Engineering, International Islamic University Malaysia (IIUM), Jalan Gombak, 53100 Kuala Lumpur, Malaysia, Kuala Lumpur, Malaysia. Email: suleyman@iium.edu.my

How to cite this article: (Harvard style)

Onundi, Y. B.; Mamun, A. A.; Al Khatib, M. F.; AlSaadi, M. A.; Suleyman, A. M., (2011). Heavy metals removal from synthetic wastewater by a novel nano-size composite adsorbent. Int. J. Environ. Sci. Tech., 8 (4), 799-806. 